\title{
Influence of Different Doses of Benzyl Adenine with Constant Naphthalin Acetic Acid on Callus Induction and Mass Multiplication of Pineapple (Ananas comosus L. Merr) var. Kew
}

\author{
Mayengbam Premi Devi, Kenny Thangjam and R.K. Dilip Singh*
}

College of Agriculture, Central Agricultural University, Iroisemba-795004, Imphal, Manipur, India

*Corresponding author

\section{A B S T R A C T}

Keywords

$\mathrm{BA}$, in vitro, Pineapple,

Proliferation, Kew, Manipur

Article Info

Accepted:

04 June 2018

Available Online:

10 July 2018
A study on influence of different doses of Benzyl Adenine (BA) combined with constant level of Naphthalin acetic acid (NAA) on callus induction, shoot multiplication, and rooting of Kew pineapple was conducted. Early callus response was observed in treatment concentrations of $2 \mathrm{mg} / \mathrm{l} \mathrm{BA}$ with $2 \mathrm{mg} / \mathrm{l} \mathrm{NAA}$ and $3 \mathrm{mg} / \mathrm{l} \mathrm{BA}$ with $2 \mathrm{mg} / \mathrm{l} \mathrm{NAA}$. Treatment $2 \mathrm{mg} / \mathrm{l} \mathrm{BA}$ with $2 \mathrm{mg} / \mathrm{l}$ NAA was resulted to replicate the maximum number of shoots (22.71 at 90 days) significantly among the treatments. Shoot length was most enhanced by $0.5 \mathrm{mg} / \mathrm{l} \mathrm{BA}$ with $2 \mathrm{mg} / \mathrm{l} \mathrm{NAA}(8.09 \mathrm{~cm}$ at 90 days) dose. Shoots in control condition developed to be shorter in all the culture periods. On sub culturing in fresh and same media of all the treatments, root initiation was observed 30 days after culture. $0.1 \mathrm{mg} / \mathrm{l} \mathrm{BA}$ with 2 $\mathrm{mg} / \mathrm{l}$ NAA was found to be significantly efficient with the number (6.33 at 90 days) and length $(2.08 \mathrm{~cm}$ at 90 days) of roots developed among the treatments. The plantlets were acclimatised at a satisfactory rate.

\section{Introduction}

Pineapple (Ananas comosus L. Merr), locally called "Kihom", is an important fruit crop suitably cultivated over the hill slopes in the state of Manipur. Kew (Syn. Smooth Cayenne) is a preferred variety on account of its nutritive as well as commercial feasibility. Kew has shy suckering habit, incapable of producing enough planting material for large scale production. Cost effective and timely production of planting material is the highlighted objective in the state's area of Kew production. Micro propagation serves the best alternative method over the traditional suckers, leading to production of large numbers of disease free, uniform planting materials in a relatively short period of time.

Micro propagation of shoot tip has been successfully carried out in pineapple (Hamad and Taha, 2008a). Many authors reported micro propagation of pineapple through enhanced axillary bud development and organogenesis (Zuraida et al., 2011; Yapo et al., 2011 Danso et al., 2008). Shoot regeneration and development were positively influenced by MS basal medium incoorporated with hormonal combination of BA and NAA in many cases (Usman et al., 
2013; Nikumbhe et al., 2014; Al-Saif et al., 2011; Kothawale et al., 2015). Akbar et al., 2003 found an effective mode of in vitro pineapple regeneration through callus using supplements of cytokinin and auxin. Also, there have been many records on better rooting of micro-plantlets with auxin:cytokinin combination in different concentrations (Nikumbhe et al., 2014; Waseem et al., 2011).

Pineapple micropropagation is well established and technically applied in many pineapple growing regions. But, Manipur state is solely dependent on the conventional method of propagation and no record of commercialised micropropagation of Kew pineapple is found in the state. So, the present study was focused on finding an applicable in vitro protocol by examining the influence of different levels of Benzyl Adenine (BA) combined with constant level of Napthalin acetic acid (NAA) on callus induction, shoot multiplication, and rooting of Kew pineapple.

\section{Materials and Methods}

Crowns of Kew pineapple were used as the source of explant. The material was collected from the Horticulture Research Farm, Andro, CAU, Imphal. For explant preparation, the leaves from the crowns were first removed carefully and were washed under running water for 5-10 mins. The terminal growing point of $1.5 \mathrm{~cm}$ diameter, was removed from the crown and placed in a beaker after washing thoroughly in distilled water.

\section{Media preparation}

One liter Murashige Scoog media (HI media) pack was dissolved in $600 \mathrm{ml}$ double distilled water in a beaker. After maintaining $\mathrm{pH}$ at 5.75.8 , water volume was made upto 1 litre. Thereafter, the media was autoclaved at $121^{\circ} \mathrm{C}$ and $1.5 \mathrm{kgcm}^{-2}$ for 20 mins. After cooling down, the hormone supplements were added as required for different treatments viz., Control, $0.1 \mathrm{mg} / \mathrm{l}$ BA+2mg/l NAA, $0.5 \mathrm{mg} / \mathrm{l}$ $\mathrm{BA}+2 \mathrm{mg} / \mathrm{lNAA}, 1 \mathrm{mg} / \mathrm{l} \mathrm{BA}+2 \mathrm{mg} / \mathrm{lNAA}$, $1.5 \mathrm{mg} / \mathrm{l} \mathrm{BA}+2 \mathrm{mg} / 1 \mathrm{NAA}, 2 \mathrm{mg} / \mathrm{BA}+2 \mathrm{mg} / 1$ $\mathrm{NAA}, 2.5 \mathrm{mg} / 1 \mathrm{BA}+2 \mathrm{mg} / \mathrm{l} \mathrm{NAA}$ and $3 \mathrm{mg} / \mathrm{l}$ $\mathrm{BA}+2 \mathrm{mg} / \mathrm{l} \mathrm{NAA}$. The media were poured into sterilized culture jars $(20 \mathrm{ml}$ each).

\section{In vitro explant sterilization, inoculation and culture conditions}

The explants were washed thoroughly under running tap water to remove any field dirt. Under laminar airflow chamber, the explants were soaked in Bavistin for 15 mins, then washed thoroughly with water for 3-4times. The explants were then treated with $0.1 \%$ $\mathrm{HgCl}_{2}$ (Nikumbhe et al., 2014) for 5 mins followed by rinsing thoroughly in distilled water for 3-4 times. The explants were trimmed down to $5 \mathrm{~mm}^{3}$ and inoculated into culture jars containing the media. Subculturing was done at 15 days interval, on fresh media for every treatment. A total of 240 crowns were inoculated, 30/treatment and $10 /$ replication. The cultures were incubated under a constant temperature of $25^{\circ} \mathrm{C}$, relative humidity of $60-70 \%$ and photoperiodic regime of $16 \mathrm{~h} /$ day provided by fluorescent light (2800 lux intensity). Data was collected every 30 days interval. Rooted plantlets from each treatment were planted in sterilised river sand soil medium. The potted plantlets were kept first in Greenhouse, then in shadehouse for 15 days each and finally transplanted in the field. Survival rate was checked after 15 days from the final transplant.

\section{Statistical analysis}

The experimental data was analyzed under complete randomized block design. The data were subjected to analysis of variance as suggested by Gomez and Gomez (1984). The significance of calculated variance was determined by "F" test. 


\section{Results and Discussion}

\section{Influence of different doses of $\mathrm{BA}$ with constant NAA on callus induction}

The shortest period for callus initiation (22.68 DAI and 23.53 days) were observed with $2 \mathrm{mg} / \mathrm{ml} \mathrm{BA}+2 \mathrm{mg} / \mathrm{ml} \mathrm{NAA}$ and $3 \mathrm{mg} / \mathrm{ml} \mathrm{BA}$ $+2 \mathrm{mg} / \mathrm{ml}$ NAA respectively, which were found to be at par (Fig. 1A). Whereas, the longest period (40.57 days) was obtained against $0.5 \mathrm{mg} / \mathrm{ml} \mathrm{BA}+2 \mathrm{mg} / \mathrm{ml}$ NAA. There were no callus formations on media without growth hormone and with $0.1 \mathrm{mg} / \mathrm{ml} \mathrm{BA}+$ $2 \mathrm{mg} / \mathrm{ml}$ NAA. The results are in accordance with the findings of (Hussain et al., 2012) and Akbar et al., (2003).

Influence of different doses of $\mathrm{BA}$ with constant NAA on shoot multiplication (shoots/explant) and length of shoots (cm)

Treatment $2 \mathrm{mg} / \mathrm{ml} \mathrm{BA}+2 \mathrm{mg} / \mathrm{ml}$ NAA replicated the maximum number of shoots at all the intervals of observations (Table 1). According to Usman et al., (2013), both cytokinin and auxin influences differentiation pattern in plants. BA and NAA interaction had significant effect on number of plantlets at multiplication. Barboza et al., (2004) showed similar hormonal combination of $2 \mathrm{mg} / \mathrm{l} \mathrm{BAP}+$ 2mg/l NAA as the best for Smooth Cayenne multiplication. At 60 days, $2 \mathrm{mg} / \mathrm{ml} \mathrm{BA}+$ $2 \mathrm{mg} / \mathrm{ml}$ NAA at par with $3 \mathrm{mg} / \mathrm{ml} \mathrm{BA}+$ $2 \mathrm{mg} / \mathrm{ml}$ NAA produced highest number of shoots. The combination of auxins and cytokinins is found to be essential for shoot induction and multiplication, depending on the plant genotype (Zuraida et al., 2011). Be and Deberg (2006) reported production of better axillary shoots at higher cytokinin concentration.

Media incorporated with $0.5 \mathrm{mg} / \mathrm{ml} \mathrm{BA}+$ $2 \mathrm{mg} / \mathrm{ml}$ NAA hormonal combination was observed to give better shoot length, although the response was at par with $2 \mathrm{mg} / \mathrm{ml} \mathrm{BA} \mathrm{+}$ $2 \mathrm{mg} / \mathrm{ml} \mathrm{NAA}$ in the beginning. However at 60 days, $1.5 \mathrm{mg} / \mathrm{ml} \mathrm{BA}+2 \mathrm{mg} / \mathrm{ml} \mathrm{NAA}$ and 0.5 $\mathrm{mg} / \mathrm{ml} \mathrm{BA}+2 \mathrm{mg} / \mathrm{ml}$ NAA led to longest shoots. But, at the end of 90 days, all treatments gave similar shoot length except the untreated and $0.1 \mathrm{mg} / \mathrm{ml} \mathrm{BA}+2 \mathrm{mg} / \mathrm{ml}$ NAA, where the shoots appeared shorter. From the investigation, the longer shoots at the initial stages of culture may be due to early growth response and development of the treatments with higher BAP levels. As the culture progressed, there developed an alteration in which lower level of BAP resulted in formation of shoots with longer shoots compared to those with higher BAP concentrations.

Fig.2

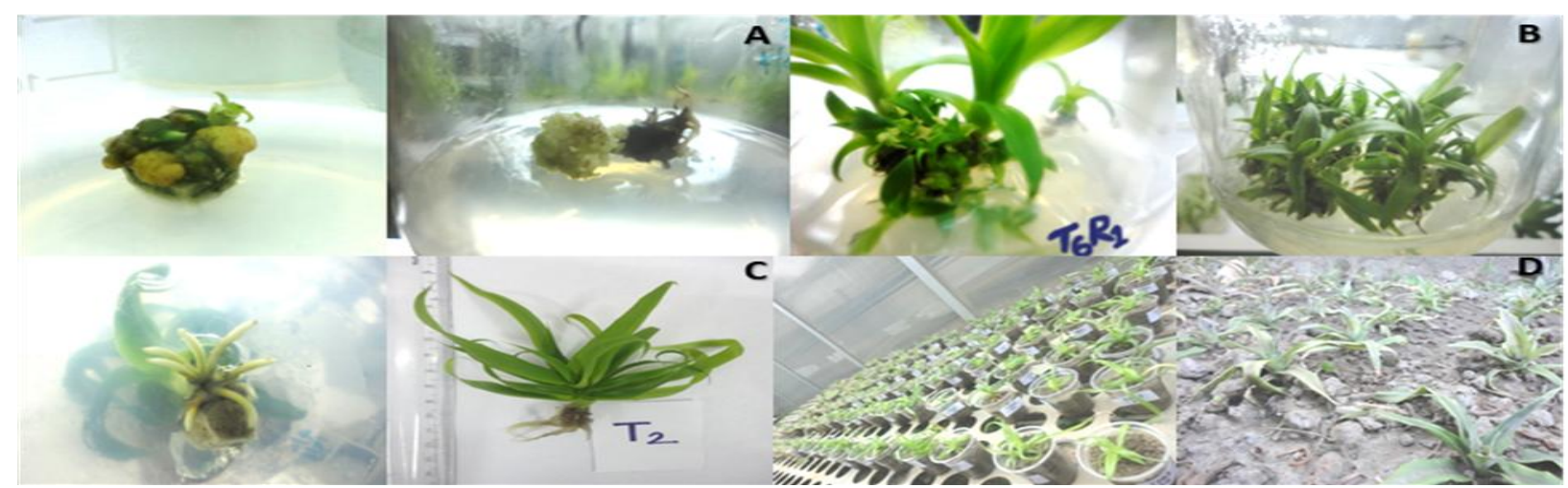

A. Callus induction in explants, B. Shoot multiplication, C. Rooting of plantlets, D. Acclimatization of in vitro plantlets 
Fig.1
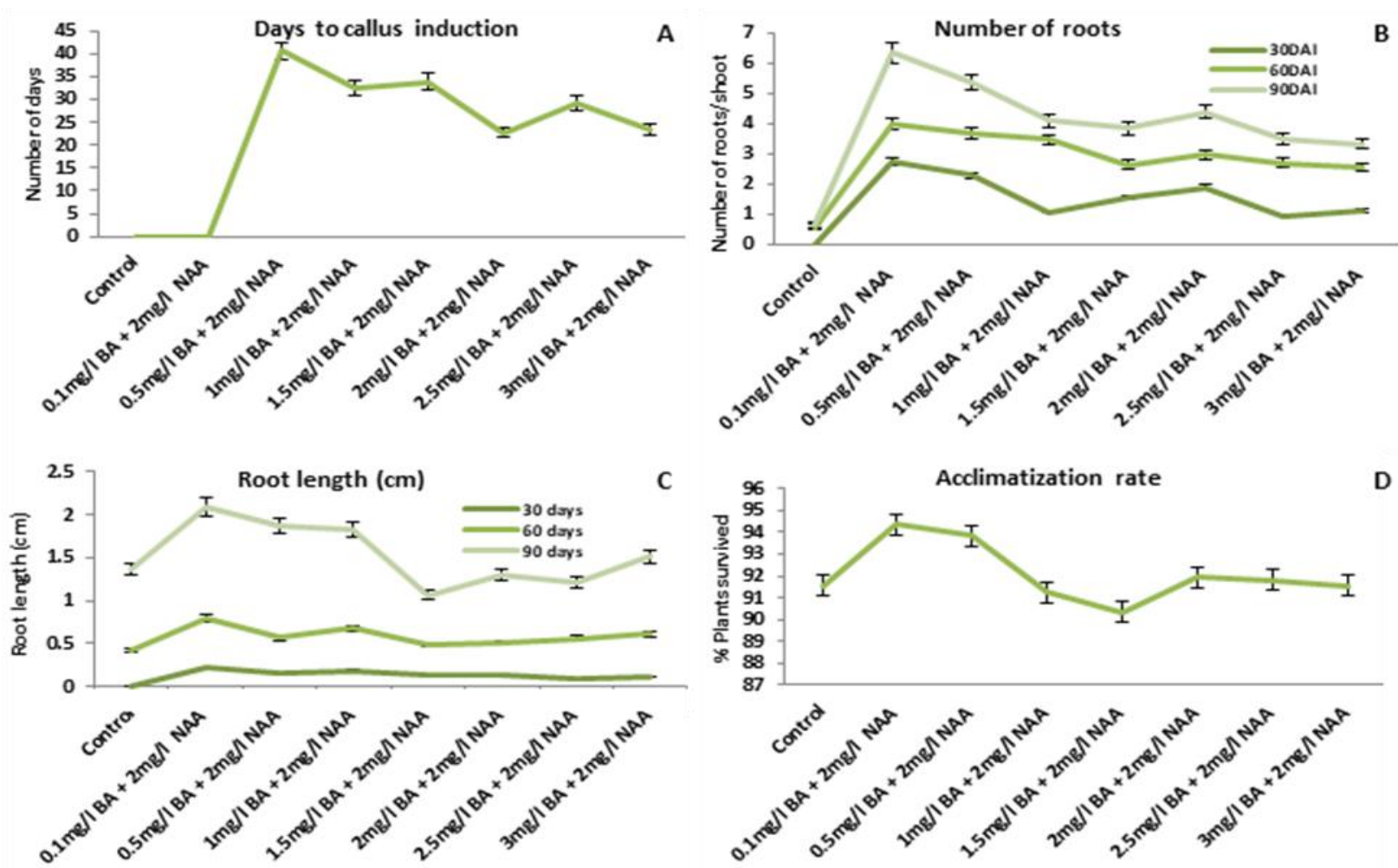

Table.1 Influence of different doses of BA with constant NAA on shoot multiplication (shoots/explant) and length of shoot $(\mathrm{cm})$

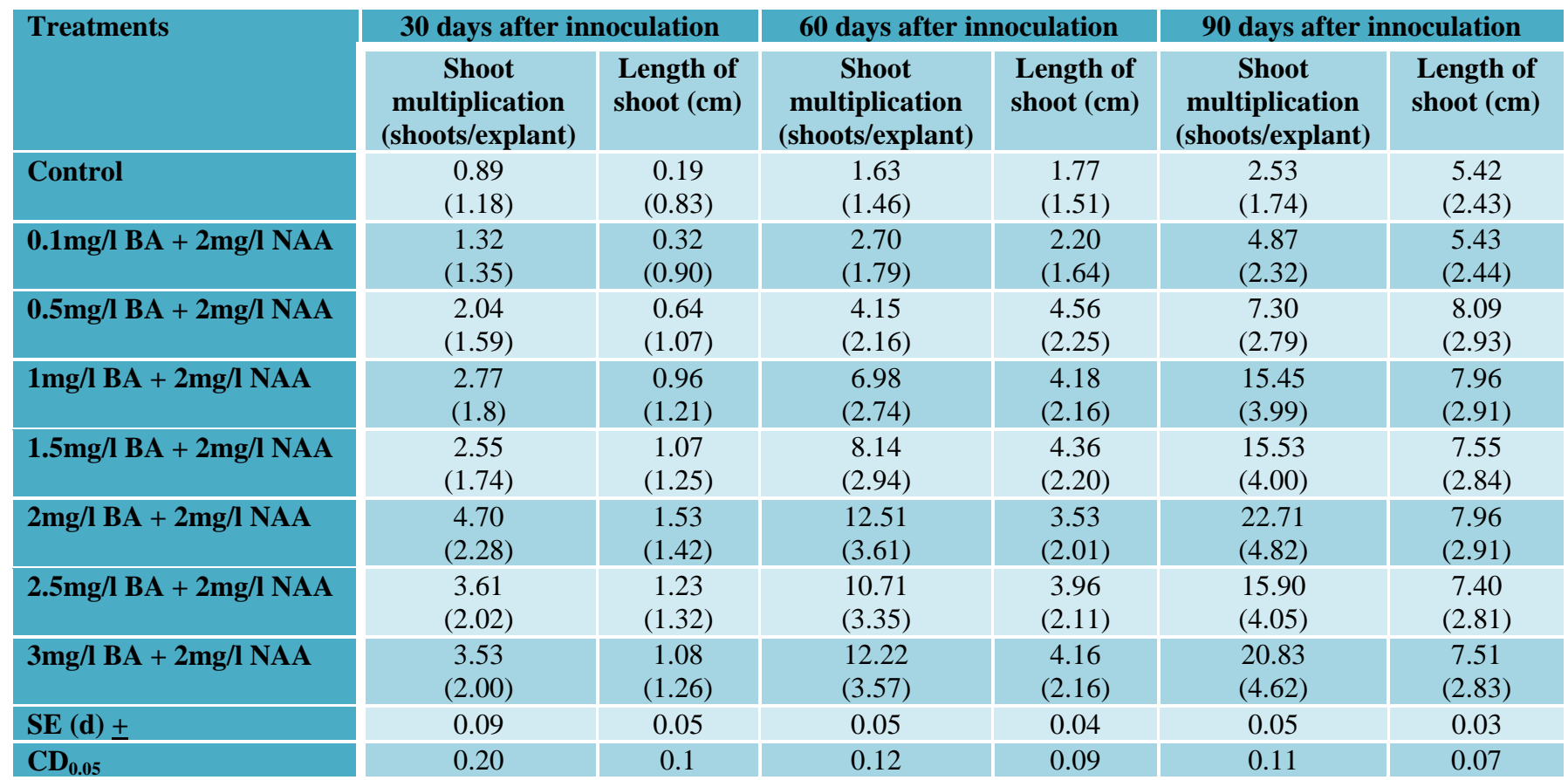

Note: Number of explants inoculated in each treatments=30. (Square root transformed values in parenthesis). 
Increase in proliferation over time could easily mask the treatment effect on shoot length, as according to Hamad and Taha (2008b). Moreover, it might be because higher cytokinin level overcomes apical dominance which releases lateral buds from dormancy (Staden et al., 2008). Hence, treatments enhancing shoot proliferation produced shorter shoots. This is supported by the results of Rao et al., (1993) and Macedo et al., (2003).

Influence of different doses of $\mathrm{BA}$ with constant NAA on root growth and development (Number and length of roots/shoot)

Different levels of BA had significant influence on production of micro-roots per shoot among the treatments, led by $0.1 \mathrm{mg} / \mathrm{ml}$ $\mathrm{BA}+2 \mathrm{mg} / \mathrm{ml}$ NAA at every culture periods (Fig. 1B). Minimum number of roots was obtained in $2.5 \mathrm{mg} / \mathrm{ml} \mathrm{BA}+2 \mathrm{mg} / \mathrm{ml} \mathrm{NAA}$ at 30 days. It can be observed from the present findings that number of micro-roots was observed to be reducing with higher BAP concentration. Higher auxin level enhances better root initiation and development, contrary to the shoot development enhanced by lower auxin and higher cytokinin. Macedo et al., (2003), reported that there was better rooting in media with lower BAP: NAA concentration in the cultures of pineapple cv. Peroira. Moreover, Bhatia and Ashwath (2002) observed that repeated sub-culturing in the same medium resulted in root initiation which could serve as both multiplication and rooting medium. They figured out that the protocol eliminates the extra step required for root initiation.

Treatment $0.1 \mathrm{mg} / \mathrm{ml} \mathrm{BA}+2 \mathrm{mg} / \mathrm{ml}$ NAA developed the maximum root lengths in all the culture periods (Fig. 1C). While, $2.5 \mathrm{mg} / \mathrm{ml} \mathrm{BA}+2 \mathrm{mg} / \mathrm{ml}$ NAA produced the shortest roots at 30 days (0.1). As discussed above, media supplemented with higher auxin content compared to cytokinin promotes root initiation and development, it also enhances elongation of the roots. Al-Amin et al., (2009) reported maximum length of roots in the same treatment that produced maximum number of roots.

\section{Acclimatization}

Rooted plantlets of each treatment were transplanted in sterilised river sand medium. Fig.1D exhibited good survival rate of plantlets with no significant difference among the treatments. Usman et al., 2013 reported the use of riverside sand as a cost effective substrate for hardening in vitro pineapple plantlets. Success of plantlets acclimatization using sand medium was reported by Jose et al., (1996). Similar result was also found by Sharma et al., (1997) in hardening of Dwarf Cavendish plantlets in sand culture.

The observations concluded with treatment combination $2 \mathrm{mg} / \mathrm{ml} \mathrm{BA}+2 \mathrm{mg} / \mathrm{ml} \mathrm{NAA}$ as most potential for Kew pineapple multiplication shoot regeneration and good crop vigor after hardening in river sand medium.

\section{Acknowledgement}

The authors are thankful to the Department of Horticulture, College of Agriculture, Central Agricultural University, Imphal for providing the facilities and resources.

\section{References}

Akbar, M. A., Biplab, K. K., and Shyamal, K. R. (2003). Callus Induction and Highfrequency Plant Regeneration of Pineapple (Ananas comosus (L.) Merr.). Plant Tissue Cult. 13(2):109116.

Al-Amin, Md., Karim, M. R., Amin, M. R, 
Rahman, S., and Mamun, A. N. M. (2009). In vitro Micropropagation of Banana (Musa spp.). Bangladesh J. Agr. Res. 34(4):645-659.

Al-Saif, A.M., Sharif Hossain, A. B. M., and Taha, R. M. (2011). Effects of benzylaminopurine and naphthalene acetic acid on proliferation and shoot growth of pineapple (Ananas comosus L. Merr) in vitro. Afr. J. Biotechnol. 10(27):5291-5295.

Barboza, S. B. S. C., Caldas, L. S., and Souza, L. A. C.(2004). Micropropagation of pineapple hybrid PExSC-52 and cultivar Smooth Cayenne. Pesqui. Agropecu. Bras. 39 (8):725-733.

Be, L. V., and Debergh, P. C. (2006). Potential low-cost micropropagation of pineapple (Ananas comosus). South Afr. J. Bot. 72: 191-194.

Bhatia, P., and Ashwath, N. (2002). Development of rapid method for micropropagation of a new pineapple (Ananascomosus (L.)Murr) clone, 'Yeppooon Gold'. ActaHort. 575:125131.

Danso, K. E., Ayeh, K. O., Oduro, V., Amiteye, S., and Amoatey, H. M. (2008). Effect of 6Benzylaminopurine and Naphthalene Acetic Acid on in vitro Production of MD2 Pineapple Planting Materials. World Appl. Sci. J. 3(4):614-619.

Gomez, K. A., and Gomez, A. A. (1984). Statistical procedures for agriculturalresearch. John Wiley and sons, Inc. London, UK (2nd edtn) pp 13-175.

Hamad, A. M., and Taha, R. M. (2008a). The effect of different hormones and Incubation Periods on in vitro proliferation of pineapple [(Ananas comosus L. Merr) cv. Smooth Cayenne] Shoot-tip culture. Pakistan J. Biol. Sci. 11(3): 386-391.

Hamad, A. M., and Taha, R. M. (2008b).
Effect of sequential subcultures on in vitro proliferation capacity and shoot formation pattern of pineapple (Ananas comosus L. Merr.) over different incubation periods. Sc.Hort. 117: 329-334.

Hussain, A., Qarshi, I. A., Nazir, H., and Ullah, I. (2012). Plant tissue culture: current status and opportunities. In: Leva A, Rinaldi LMR (eds) Recent advances in plant in vitro culture. InTech, Rijeka, pp 1-28. ISBN:978953-51-0787-3.

Jose, J. O., Radha, C. T., and Aravindakshan, K. (1996). In vitro multiplication of pineapple through enhanced release of axillary buds. J Appl Hortic (Navsari) $2(1 / 2): 82-85$.

Kothawale, S. P., Kshirsagar, A. B., and Zahid, I. H. (2015). Response of BA and NAA on shoot proliferation of Punica Granatum L. Bionano Frontier. 8(1).

Macedo, C. E. C. de, Silva, M. G. da, Nobrega, F. S. da, Martins, C. P., Barroso, P. A. V., and Alloufa, M. A. I. (2003). The effect of NAA and BAP concentrations on the micropropagation and hydroponic cultures of pineapple. Rev Bras Frutic. 25(3): 501-504.

Nekumbhe, P. H., Sonavane, P. N., and Sable, P. A. (2014). In vitro technology for Propagation of pineapple (Ananas comosus L.) cv. Kew. Internat. J. agric. Sc. 10(1):172-175.

Rao, Y. S., Mathew, M. A., Madhusoodanan, K. J., and Naidu, R.(1993). Multiple shootregeneration in vanilla (Vanilla planifolia).J. Plantation Crops. 21: 351-354.

Sharma, G. L., Tiwary, B. L., and Pandey, S. D. (1997). Rapid in vitro mass propagation of banana and changes in bio-chemical constituents at various cultural stages. Indian J. Hort. 54 (2): 
128-131.

Staden, J. van, Zazimalova, E., and George, E. F. (2008) Chapter 6: Plant Growth Regulators II: Introduction, Cytokinins, their Analogues and Antagonists. In: George EF, Hall MA and De Klerk G-J (eds): Plant Propagation by Tissue Culture 3rd Edition. Volume 1 The Background, Springer, Dordrecht, The Netherlands, pp. 205-226.

Usman, I. S., Abdulmalik, M. M., Sani, L. A., and Muhammad, A. N. (2013). Development of an efficient protocol for micropropagation of pineapple (Ananas comosus L. Var. Smooth cayenne). Afri. J. Agric. Res. 8(18): 2053-2056.

Waseem, K., Jilani, M. S., Jaskani, M. J., Khan, M. S., Kiran, M., and Khan, G. U. (2011). Significance of different plant growth regulators on the regeneration of chrysanthemum plantlets (Dendranthema morifolium L.) through shoot tip culture. Pak. J. Bot. 43(4): 1843-1848.

Yapo, E.S., Tanoh, H.K., Mongomaké, K., Justin, Y.K., Patrice, K., and JeanMichel, M. (2011). Regeneration of Pineapple (Ananas comosus L.) Plant through Somatic Embryogenesis. $J$. Plant Biochem. Biotech. 20(2):196204.

Zuraida, A. R., Nurul Shahnadz, A. H., Harteeni, A., Roowi, S., Che Radziah, C. M. Z. and Sreeraman, S. (2011). A novel approach for rapid micropropagation of maspine pineapple (Ananas comosus L.) shoots using liquid shake culture system. Afr. J. Biotechnol. 10(19): 3859-3866.

\section{How to cite this article:}

Mayengbam Premi Devi, Kenny Thangjam and Dilip Singh, R.K. 2018. Influence of Different Doses of Benzyl Adenine with Constant Naphthalin Acetic Acid on Callus Induction and Mass Multiplication of Pineapple (Ananas comosus L. Merr) var. Kew. Int.J.Curr.Microbiol.App.Sci. 7(07): 136-142. doi: https://doi.org/10.20546/ijcmas.2018.707.017 